\title{
Identification and characterization of two novel centriolar appendage component proteins
}

\author{
JM Schrøder ${ }^{*}$, M Rogowski ${ }^{2}$, L Jakobsen ${ }^{1}$, K Vanselow $^{1}$, S Geimer ${ }^{2}$, LB Pedersen ${ }^{3}$, JS Andersen ${ }^{1}$ \\ From First International Cilia in Development and Disease Scientific Conference (2012) \\ London, UK. 16-18 May 2012
}

The mother centriole forms the basis of the primary cilium. As the cilium assembles, the mother centriole matures and differentiates into the basal body, and a number of fibrous structures are formed that add to the complexity, including the distal and subdistal appendages. A number of the proteins corresponding to these structures are identified already, but given the complexity of the basal body, the macromolecular composition of some of these appendages remain unknown. To date, the proteins ninein and Cep170 are believed to be a part of the subdistal appendages, and Cep164, outer dense fiber 2, ODF2/ cenexin, Cep290, Ofd1 compose the distal appendages. Most of these appendage structures have been reported to play a role for cilia assembly. We previously characterized the centrosome proteome of human lymphoblastic KE-37 cells using quantitative mass spectrometry, which identified 40 novel candidate proteins (Jakobsen et al., 2011). Using immunoflourescence- and immunogold electron microscopy on different human culture cells we identified proteins localizing asymmetrically to the centrioles, and two of these appeared to be new appendage proteins, one distal- (Cep37) and one subdistal (Cep128). Interestingly, in addition Cep37 also localize to the ciliary tip and more faintly along the axoneme. Preliminary results indicate that depletion of Cep37 reduces length of cilia in RPE cells. Cep128 does not affect RPE or hFF cells ability to form primary cilia, but they do show a higher number of pericentriolar dense bodies or satellites as well as a higher number of non exocytotic vesicles in line with the cilium.

\footnotetext{
Author details

${ }^{1}$ University of Southern Denmark, Denmark. ${ }^{2}$ University of Bayreuth, Germany. ${ }^{3}$ University of Copenhagen, Denmark.
}

* Correspondence: jms@bmb.sdu.dk

'University of Southern Denmark, Denmark

Full list of author information is available at the end of the article
Published: 16 November 2012

doi:10.1186/2046-2530-1-S1-P44

Cite this article as: Schrøder et al:: Identification and characterization of two novel centriolar appendage component proteins. Cilia 2012 1(Suppl 1):P44.
Submit your next manuscript to BioMed Central and take full advantage of:

- Convenient online submission

- Thorough peer review

- No space constraints or color figure charges

- Immediate publication on acceptance

- Inclusion in PubMed, CAS, Scopus and Google Scholar

- Research which is freely available for redistribution

Submit your manuscript at www.biomedcentral.com/submit
C Biomed Central
C Biomed Central

(c) 2012 Schrøder et al; licensee BioMed Central Ltd. This is an Open Access article distributed under the terms of the Creative Commons Attribution License (http://creativecommons.org/licenses/by/2.0), which permits unrestricted use, distribution, and reproduction in any medium, provided the original work is properly cited. 